\title{
Search for Serratia
}

\author{
W. A. BLACK ${ }^{1}$ AND R. HODGSON \\ From the University Department of Bacteriology, Royal Infirmary, Glasgow
}

SYNOPSIS During a four-month period an intensive effort was made to isolate and identify every Serratia marcescens strain present in the clinical material received for bacteriological assessment in the laboratory. Ten strains were isolated from eight patients, the organism possibly being responsible for infection in five of these patients. Serratia marcescens is thus commoner than expected and it is difficult to explain the fact that there are so few references to it as a pathogen in the British literature.

The frequency with which Serratia marcescens is implicated as a pathogen in the American literature (Atlas and Belding, 1968; Dodson, 1968; Nelms, Goldman, O'Donnell, and Henry, 1968; Ringrose, McKown, Felton, Barclay, Muchmore, and Rhodes, 1968; Alexander, Reichenbach, and Merendino, 1969; Altemeier, Culbertson, Fullen, and McDonough, 1969) presents a striking contrast to the situation that exists in Great Britain where this organism has only rarely been considered a cause of morbidity or mortality (Milner, 1963; McCracken and Lipscomb, 1965; Black, Pollock, and Batchelor, 1967; Hughes and Hopper, 1970). This situation has drawn comment in a recent leading article (British Medical Journal, 1969) which tentatively suggested that one reason for the comparative rarity of reports from outside the USA might well be the failure of some workers to identify correctly the organism when it is isolated in the laboratory. Although this hypothesis seemed a little tenuous since the criteria for the bacteriological identification of Serratia marcescens are well established (Edwards and Ewing, 1962; Cowan and Steel, 1965), the alternative explanation, namely, that there is a higher natural frequency of this organism in the clinical material received in the laboratory in the USA than in, for example, Great Britain, has never been adequately substantiated. It occurred to us, therefore, that it would be a useful exercise to establish as a baseline the absolute incidence of Serratia marcescens in the material received for bacteriological assessment in this laboratory, and thereafter to attempt to determine the clinical relevance of the isolates by means of a follow-up study.

\footnotetext{
${ }^{1}$ Present address: St. Joseph's Hospital, London, Ontario, Canada
}

Received for publication 1 October 1970.

\section{Materials and Methods}

The project, which extended over four months, was $c$ carried out at a Glasgow 800-bed teaching hospital $₹$ with wards for all of the major specialities with the $\overrightarrow{6}$ exception of paediatrics. During this period 20,500 specimens were examined in the bacteriology diagnostic laboratory.

Since only $0.8 \%$ of Serratia marcescens strains can ferment lactose rapidly (Edwards and Ewing, 1962), each of the above specimens was plated on MacConkey's agar (Oxoid MacConkey no. 2-CM 109) and any organism which appeared as a nonlactose fermenter or weak lactose-fermenter after overnight incubation on this medium was selected for further biochemical investigation. The tests used, which were all standard methods based on the work of Edwards and Ewing (1962) and Cowan and Steel (1965), are shown in Table I. A total of 219 organisms which were apparent non-lactose fermenters or weak lactose fermenters were submitted to the 3 entire battery of tests. In addition, there were many 0 organisms which, although appearing as non-lactose fermenters on the MacConkey screen, were obviously from their appearance on the accompanying diagnostic routine blood agar plates either swarming $\sigma$ Proteus or pigmented Pseudomonads. In these cases $N$ a few simple confirmatory tests sufficed for the $N$ purposes of this study. As a further safeguard against $\omega$ missing any Serratia strains during this period, another 276 consecutive organisms which were lactose-fermenters on the MacConkey medium were $\stackrel{D}{\oplus}$ tested for deoxyribonuclease (DNase) production since this is a characteristic of Serratia marcescens (Black, Hodgson, and McKechnie, 1971) and any strains giving a positive or weakly positive result $\frac{\stackrel{\rho}{\mathbb{D}}}{\mathrm{O}}$ were fully investigated biochemically by the tests $\varrho$ shown in Table I. 


\begin{tabular}{|c|c|c|}
\hline $\begin{array}{l}\text { Nitrate reduction } \\
\text { Motility } \\
\text { Catalase } \\
\text { Oxidase } \\
\text { Glucose (acid/gas) } \\
\text { O-F test }\end{array}$ & $\begin{array}{l}\text { Indole (Kovacs) } \\
\text { Methyl Red } \\
\text { Voges-Proskauer } \\
\text { Citrate (Simmons') } \\
\text { KCN } \\
\text { Malonate } \\
\text { Gluconate }\end{array}$ & $\begin{array}{l}\mathrm{H}_{2} \mathrm{~S} \text { (TSI agar) } \\
\text { Gelatin liquefaction }\left(22^{\circ} \mathrm{C}\right) \\
\text { Arginine dihydrolase } \\
\text { Lysine decarboxylase } \\
\text { Ornithine decarboxylase } \\
\text { Urease } \\
\text { Phenylalanine deaminase } \\
\text { ONPG }\end{array}$ \\
\hline $\begin{array}{l}\text { Lactose } \\
\text { Adonitol } \\
\text { Inositol }\end{array}$ & $\begin{array}{l}\text { Arabinose } \\
\text { Raffinose } \\
\text { Rhamnose } \\
\text { Dulcitol } \\
\text { DNase }\end{array}$ & $\begin{array}{l}\text { Sucrose } \\
\text { Mannitol } \\
\text { Sorbitol } \\
\text { Salicin }\end{array}$ \\
\hline
\end{tabular}

Table I Biochemical tests used in the identification of the isolates

The antibiotic sensitivities of the Serratia marcescens isolates were tested on Columbia agar (Oxoid CM 331) using Mast sensitivity discs (Mast Laboratories, Liverpool). The technique used was that of Stokes (1968) which involves the direct comparison on each plate of the test strain and a control organism (Escherichia coli NCTC 10418) of known sensitivity.

\section{Results}

As can be seen from Table II, 10 Serratia strains were isolated from eight patients. None of these isolates produced pigment. In four of the eight patients the organisms were isolated from sputum and in the remaining four from urine, three being from catheter specimens and one from a midstream specimen.

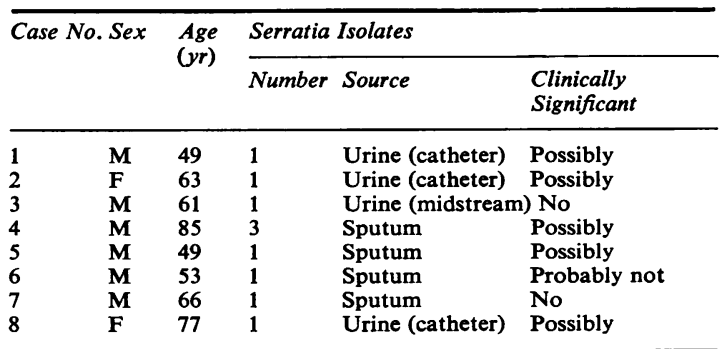

Table II Source and clinical significance of the Serratia isolates

Table III shows the antibiotic sensitivities of the isolates. All were resistant to ampicillin and cephaloridine and sensitive to kanamycin, gentamycin, and carbenicillin. The degree of sensitivity varied to tetracycline, streptomycin, nitrofurantoin, nalidixic acid, and colomycin.

In Table IV the bacteriological identity of the 219 non-lactose fermenters is given and also the additional number of swarming Proteus and pigmented

\begin{tabular}{lllllllll}
\hline Antibiotic & \multicolumn{1}{l}{ Case Number } \\
\cline { 2 - 8 } & 1 & 2 & 3 & 4 & 5 & 6 & 7 & 8 \\
\hline Ampicillin & - & - & - & - & - & - & - & - \\
Tetracycline & - & - & +1 & $+1-$ & $+1-$ & - & $+1-$ & $+1-$ \\
Streptomycin & + & + & + & + & - & - & + & - \\
Nitrofurantoin & - & - & + & $+1-$ & $+1-$ & +1 & + & $+1-$ \\
Nalidixic acid & + & +1 & + & + & + & + & + & + \\
Kanamycin & + & + & + & + & + & + & + & + \\
Cephaloridine & + & - & - & - & - & - & - & - \\
Colomycin & - & +1 & $+1-$ & + & $+1-$ & - & + & $+1-$ \\
Carbenicillin & + & + & + & + & + & + & + & + \\
Gentamycin & + & + & + & + & + & + & + & + \\
\hline
\end{tabular}

Table III Antibiotic sensitivity pattern of the Serratia isolates

$$
\begin{array}{ll}
+ & =\text { Sensitive } \\
+/- & =\text { Moderately resistant } \\
-\quad & =\text { Resistant }
\end{array}
$$

\begin{tabular}{lrl}
\hline Organism & No. of Isolates & $\begin{array}{l}\text { Percentage of Non- } \\
\text { lactose Fermenters }\end{array}$ \\
\hline Serratia marcescens & 10 & $0 \cdot 88$ \\
Enterobacter cloacae & 19 & $1 \cdot 67$ \\
Enterobacter hafniae & 6 & $0 \cdot 53$ \\
Enterobacter aerogenes & 5 & $0 \cdot 44$ \\
Enterobacter liquefaciens & 1 & 0.09 \\
Klebsiella & 13 & $1 \cdot 15$ \\
Escherichia coli & 62 & $5 \cdot 46$ \\
Proteus & 40 & 3.52 \\
Providence & 5 & $0 \cdot 44$ \\
Salmonella typhimurium & 4 & $0 \cdot 35$ \\
Pseudomonas & 15 & $1 \cdot 32$ \\
Alkaligenes & 12 & $1 \cdot 06$ \\
Acinetobacter & 16 & $1 \cdot 41$ \\
Aeromonas & 2 & $0 \cdot 18$ \\
Flavobacterium & 2 & $0 \cdot 18$ \\
Unclassified & 7 & $0 \cdot 62$ \\
Total & 219 & - \\
Proteus & 727 & 64.05 \\
Pseudomonas & 189 & 16.65 \\
Final total & 1,135 & $100 \cdot 00$ \\
\hline
\end{tabular}

Table IV Biochemical classification of 219 organisms appearing as non-lactose fermenters on MacConkey's medium

${ }^{1}$ Swarming Proteus and pigmented Pseudomonads which were identified during the study by colonial morphology and a short set of biochemical tests.

Pseudomonads identified by the short set of biochemical tests. From this table it can be seen that Serratia marcescens represented $0.88 \%$ of the total of 1,135 organisms which appeared as non-lactose fermenters on MacConkey's medium.

\section{Discussion}

This study had two objectives, the first being a comparison of the frequency of isolation of Serratia marcescens in this country and in the USA, and the second a retrospective assessment of the clinical significance of the Serratia strains which w'ere isolated in this laboratory during the study. 
At the outset, it must be appreciated that, in bacteriology especially, the comparison of data from different sources is fraught with danger. This point has been emphasized recently in a leading article (Lancet, 1970) where it was shown that results from different centres could still vary even when identical material was being examined by a standard technique. It follows, therefore, that it cannot immediately be assumed from the figures presented in Table $\mathrm{V}$ that the incidence of Serratia, both absolutely and relative to the other members of the Klebsiella-EnterobacterSerratia group, varies widely from area to area. Indeed, two of the groups of workers cited in the table themselves tread cautiously in comparing their results with those of other series. Weil, Benjaminson, and de Guzman (1964), for example, make the point that much of the literature on the KlebsiellaEnterobacter-Serratia group is of little value because of confusion in nomenclature and lack of detailed description of organisms involved, and Braunstein, Gibson, and Tucker (1969) are puzzled by the fact that the relative proportion of Enterobacter species in their series differs from most other results published previously.

Notwithstanding these difficulties, it is certainly possible to gain a reasonably accurate idea of what is happening elsewhere, and the veritable spate of publications from the USA in recent years naming Serratia marcescens as a pathogen (Atlas and Belding, 1968; Dodson, 1968; Nelms et al, 1968; Ringrose et al, 1968; Allen and Conger, 1969; Alexander et al, 1969; Altemeier et al, 1969; Cabrera, 1969; Quintiliani and Gifford, 1969) would certainly indicate that the organism is a fairly common cause of disease in that country. Our own impression, however, which incidentally was shared by all of the British bacteriologists with whom we had discussed this topic, was that Serratia marcescens is an uncommon, if not rare, clinically significant isolate in the bacteriology laboratory in this country.

In order to verify that this was indeed so in this laboratory, and that Serratia marcescens was not merely being dismissed either as clinically incon- sequent or as an unidentified coliform organism, we chose to identify every single organism, irrespective 0 of its clinical significance, which could possibly be Serratia marcescens. The figure in Tables II and III of 10 organisms, three of these from one patient, ino a period of four months, represents, therefore, ao value which one would expect to be in excess of that $\frac{\bar{s}}{7}$ which would have been found if normal procedures $\mathbb{Q}$ in bacteriological reporting had been followed. Eveno allowing for this, however, and for the difficulties of ${ }^{\mathrm{S}}$ comparison which we have already mentioned, we. were still rather surprised to find as many Serratia $\vec{\omega}$ as we did.

Much more surprising, however, was the findingo that in five of the eight patients the Serratia marces-i cens isolated was possibly behaving as a pathogen,,+ although it is difficult to be certain about this as ours. was a retrospective assessment. The details of these cases are given below and summarized in Table II.의

CASE 1 (s.P.)

Cystoscopy 20 January 1970. Cardiac arrest leaving theatre. Tracheostomy 20 January until 3 February. $\vec{\theta}$ Developed bronchopneumonia 6 February. Proteus.isolated, doubtful significance. Urinary tract infec- $\square$ tion 7 February 1970-Serratia isolated. Patient died 10 February before specimen could be repeated. Necropsy report: hypostatic bronchopneumonia, midbrain thrombosis, ureteric stenosis, and pyelonephritis.

CASE 2 (M.F.)

Diabetic with peripheral vascular disease. Bilateralo amputation of legs. Serratia isolated from urine (catheter specimen) in significant numbers. Latero Esch. coli and Ps. aeruginosa also isolated.

CASE 3 (J.S.)

Admitted with abdominal haematoma. Died later due to rupture of small aortic aneurysm. Serratia $\triangle$ present in urine in small numbers $(1,800 / \mathrm{ml})$ on one $\frac{}{3}$ occasion.

\begin{tabular}{|c|c|c|c|c|}
\hline \multirow[t]{2}{*}{ Series } & \multirow{2}{*}{$\begin{array}{l}\text { Duration of Series } \\
\text { (mth) }\end{array}$} & \multicolumn{2}{|l|}{ Number of Isolates } & \multirow{2}{*}{$\begin{array}{l}\text { Serratia as a \% of Klebsiella-Enterobacter- } \\
\text { Serratia Group }\end{array}$} \\
\hline & & Klebsiella/Enterobacter & Serratia & \\
\hline Weil et al (1964) & 27 & 434 & 1 & 0.2 \\
\hline Eickhoff et al (1966) & 6 & 303 & 3 & 1.0 \\
\hline Edmondson and Sanford (1967) & 3 & 155 & 14 & $8 \cdot 4$ \\
\hline Braunstein et al (1969) & Not known & 104 & $\mathbf{0}$ & 0.0 \\
\hline Domingue et al (1969) & 6 & 596 & 40 & 6.4 \\
\hline Kunz (1969) & 1 & 379 & 69 & $15 \cdot 4$ \\
\hline Roland (1969) & 6 & 68 & 1 & $1 \cdot 5$ \\
\hline Blick et al (1970) & 4 & 511 & 10 & 1.9 \\
\hline
\end{tabular}

Table V Comparison of the present series with those of some American workers 
CASE 4 (C.MCK)

Exacerbation of chronic bronchitis with congestive cardiac failure February 1970. Serratia isolated from sputum on three occasions. Marked clinical improvement with carbenicillin therapy which cleared the organism from the sputum. Patient readmitted May 1970 and died shortly afterwards with respiratory failure. No bacteriological studies done on this occasion.

\section{CASE 5 (G.H.)}

Myocardial infarction with heart block. Clinical chest infection on 30 March 1970. Serratia isolated from sputum 1 April. Patient died from cardiac arrest on 2 April before specimen could be repeated.

\section{CASE 6 (J.MCL.)}

Admitted as emergency with pneumonia. Penicillin/ streptomycin started arbitrarily 26 March 1970. Patient improved clinically. Sputum sent to laboratory on 2 April grew Serratia. Patient discharged without further bacteriology being done.

\section{CASE 7 (O.B.)}

Cholecystectomy. Serratia present in small numbers in sputum. Probably oropharyngeal commensals.

\section{CASE 8 (A.N.)}

Cholecystectomy. Pancreatitis. Peritonitis. Acute tubular necrosis. Serratia urinary tract infection 2 April 1970. Patient died 3 April before specimen could be repeated.

From the case summaries it can be seen that in cases $1,2,4,5$, and 8 the Serratia was possibly implicated as a pathogen and in cases 3 and 7 was merely a contaminant. The assessment of case 6 was rather more difficult, although we have said that in this instance the Serratia isolated was probably not a pathogen.

If, however, we accept that Serratia marcescens is isolated in the laboratory more commonly than is realized and that many of these isolates may be assuming the role of pathogens, it becomes extremely difficult to account for the fact that there are so few reports involving this organism in the British literature. It can certainly be appreciated that in the busy routine laboratory many of these isolates causing minor infections may be reported as "coliforms' but it still does not explain the lack of major outbreaks of infection due to Serratia which are apparently so common in the USA, since in these instances one would expect the causative organism to be fully identified.

In many of the American reports, the tendency has been for Serratia marcescens to behave as an opportunistic pathogen, affecting mainly patients who are debilitated after major surgery or whose natural defence mechanisms have been depressed by steroids, cytotoxic drugs, or broad-spectrum antibiotics (Dodson, 1968; Altemeier et al, 1969). It has also frequently contaminated items of hospital equipment and caused subsequent nosocomial infection (Ringrose et al, 1968; Johanson, Pierce, and Sanford, 1969). In this country, however, in similar situations the opportunist has almost always been Pseudomonus aerugincsa (Phillips, 1967; Tinne, Gordon, Bain, and Mackey, 1967) and not Serratia marcescens. This, of course may simply be due to the fact that Ps. aeruginosa is less common in the USA than in Great Britain but we have been unable to find any reliable studies in the literature to support this unlikely contention.

There is, however, complete agreement between British and American workers that opportunistic Gram-negative infection is a commonplace occurrence, and it should therefore be interesting to see whether, as time elapses, Serratia marcescens will come to achieve in this country the relative prominence that it has attained in the USA in recent years.

We wish to express our gratitude to Dr J. C. J. Ives for constant encouragement and advice and to Miss Margaret Ferguson for technical assistance.

\section{References}

Alexander, R. H., Reichenbach, D. D., and Merendino, K. A. (1969). Serratia marcescens endocarditis. Arch. Surg., 98, 287-291.

Allen, S. D., and Conger, K. B. (1969). Serratia marcescens infections of the urinary tract: A nosocomial infection.J. Urol. (Baltimore), 101, 621-623.

Altemeier, W. A., Culbertson, W. R., Fullen, W. D., and McDonough, J. J. (1969). Serratia marcescens septicaemia. Arch. Surg., 99, 232-238.

Atlas, E., and Belding, M. E. (1968). Serratia marcescens arthritis requiring amputation. J. Amer. med. Ass., 204, 167-169.

Black, W. A., Hodgson, R., and McKechnie, A. (1971). The use of deoxyribonuclease production as a screening test for Serratia marcescens - an evaluation of three methods. J. clin. Path. 24 , in the press.

Black, W. A., Pollock, A., and Batchelor, E. L. (1967). Fatal transfusion reaction due to Serratia marcescens. J. clin. Path., 20, 883-886.

Braunstein, H., Gibson, B. C., and Tucker, E. B. (1969). Species distribution of the Klebsiella-enterobacter group at the University of Kentucky Medical Center. Sth. med.J. (Bgham, Ala.), 62, 1491-1495.

British Medical Journal (1969). Serratia Septicaemia. (Leading article.) Brit. med. J., 4, 756-757.

Cabrera, H. A. (1969). An outbreak of Serratia marcescens, and its control. Arch. intern. Med., 123, 650-655.

Cowan, S. T., and Steel, K. J. (1965). Manual for the Identification of Medical Bacteria. Cambridge University Press, London.

Dodson, W. H. (1968). Serratia marcescens septicaemia. Arch. intern. Med., 121, 145-150.

Domingue, G. J., Dean, F., and Miller, J. R. (1969). A diagnostic schema for identifying enterobacteriaceae and miscellaneous Gram-negative bacilli. Amer. J. clin. Path., 51, 62-70.

Edmondson, E. B., and Sanford, J. P. (1967). The Klebsiella-enterobacter (aerobacter)-Serratia group. Medicine (Baltimore), 46, 323-340.

Edwards, P. R., and Ewing, W. H. (1962). Identification of enterobacteriaceae, 2 nd ed. Burgess, Minneapolis. 
Eickhoff, T. C., Steinhauer, B. W., and Finland, M. (1966). The Klebsiella-enterobacter-Serratia division. Ann. intern. Med., 65, 1163-1179.

Hughes, R. A. C., and Hopper, P. K. (1970). Serratia septicaemia. Brit. med. J., 2, 114.

Johanson, W. G., Pierce, A. K., and Sanford, J. P. (1969). Changing pharyngeal bacterial flora of hospitalized patients. New Engl. J. Med., 281, 1137-1140.

Kunz, L. J. (1969). In: How far to go with enterobacteriaceae. (A roundtable discussion). J. infect. Dis., 119, 197-213.

Lancet (1970). Can bacteriologists agree? (Leading Article.) Lancet, $1,664$.

McCracken, A. W., and Lipscomb, F. E. (1965). Serratia marcescens infection complicating peritoneal dialysis. Brit. med. J., 1, 1536-1537.

Milner, P. F. (1963). The differentiation of enterobacteriaceae infecting the urinary tract. J. clin. Path., 16, 39-45.

Nelms, D. K., Goldman, A. S., O'Donnell, A. A., and Henry, M. J. (1968). Serratia marcescens osteomyelitis in an infant. $J$. Pediat., 72, 222-227.
Phillips, I. (1967). Pseudomonas aeruginosa respiratory tract infections in patients receiving mechanical ventilation. J. Hyg. (Lond.), 65, 229-235.

Quintiliani, R., and Gifford, R. H. (1969). Endocarditis from Serratia marcescens. J. Amer. med. Ass., 208, 2055-2059.

Ringrose, R. E., McKown, B., Felton, F. G., Barclay, B. O., Muchmore H. G., and Rhodes, E. R. (1968). A hospital outbreak of Serratia marcescens associated with ultrasonic nebulisers. Ann. intern. Med., 69, 719-729.

Roland, F. P. (1969). A six-month study of Gram-negative bacilli in a paediatric ward. Clin. Med., 76, 19-23.

Stokes, E. J. (1968). Clinical Bacteriology, 3rd ed, p. 176. Arnold, London.

Tinne, J. E., Gordon, A. M., Bain, W. H., and Mackey, W. A (1967). $\overrightarrow{0}$ Cross-infection by Pseudomonas aeruginosa as a hazard of intensive surgery. Brit. med. J., 4, 313-315.

Weil, A. J., Benjaminson, M. A., and Guzman, B. C. de (1964). The Klebsiella-Aerobacter-Serratia division: Its role in common infections of man. Trans. N.Y. Acad. Sci., 27, 65-72. 